\title{
PELATIHAN DAN PEMBERDAYAAN TUNAS SUSTAINABLE DEVELOPMENT GOALS (SDGS) SISWA TINGKAT SMA/MA SEDERAJAT DI KOTA PEKANBARU UNTUK MEWUJUDKAN TUJUAN SUSTAINABLE CITIES AND COMMUNITIES DAN RESPONSIBLE CONSUMPTION AND PRODUCTION
}

\author{
Alfajri $^{1)}$, Suwignyo ${ }^{2)}$, Luerdi $^{3)}$ \\ 1),3)Program Studi Ilmu Hubungan Internasional, Fisipol Universitas Abdurrab \\ ${ }^{2)}$ Program Studi Profesi Dokter, FKIK Universitas Abdurrab \\ Email: alfajri@univrab.ac.id
}

\begin{abstract}
ABSTRAK
Artikel ini bertujuan untuk mendeskripsikan bagaimana kegiatan pengabdian memberikan manfaat bagi generasi muda, khususnya siswa tingkat SMA/MA sederajat dalam merespon masalah sampah di kota Pekanbaru. Bahwa masyarakat termasuk siswa belum memiliki cukup kesadaran terhadap Tujuan Pembangunan Berkelanjutan (SDGs) bila dikaitkan dengan masalah sampah merupakan alasan utama pelaksanaan kegiatan pengabdian ini. Kegiatan pengabdian dilaksanakan dalam bentuk pelatihan dan pemberdayaan yang melibatkan keaktifan peserta. Kegiatan ini telah menunjukkan beberapa hasil yang positif seperti pemahaman peserta terhadap masalah sampah di Kota Pekanbaru dan tujuan SDGs serta kesadaran terhadap peran dan kontribusi mereka dalam menciptakan lingkungan bebas sampah. Ini diharapkan dapat membantu mencapai dua dari tujuan SDGs yaitu; kota dan masyarakat yang berkelanjutan; dan konsumsi dan produksi yang bertanggungjawab dari pihak non-pemerintah.
\end{abstract}

Kata kunci: SDGs, sampah, kota dan komunitas yang berkelanjutan, konsumsi dan produksi yang bertanggungjawab.

\section{ABSTRACT}

This article aims to describe how the community service benefits young generations, especially students of high school in responding the trash problem in Pekanbaru. The fact that society including students did not possess enough awareness of the Sustainable Development Goals (SDGs) regarding thrash problem was the main reason for the community service event. The community service was conducted in the form of training and empowerment which emphasized the participants' active engagement. The event has shown some positive outputs such as the participants' understanding on trash problem and the SDGs' goals as well as their awareness of role and contribution in creating freetrash environments. These are expected to meet two of the SDGs' goals; sustainable cities and communities; and responsible consumption and production from non-governmental community side.

Key words: SDGs, trash, sustainable cities and communities, responsible consumption and production. 


\section{PENDAHULUAN}

Pelaksanaan tanggungjawab terhadap Tujuan Pembangungan Berkelanjutan (Sustainable Development Goals-SDGs) yang diinisiasi oleh PBB yang merupakan lanjutan dari program Millenium Development Goals (MDGs) masih sangat rendah di tengah-tengah siswa tingkat SMA/MA sederajat kota Pekanbaru; terutama untuk tujuan SDGs no.11 (sustainable cities and communities) dan no.12 (responsible consumption and production). Tidak ada kewajiban hukum untuk melaksanakan SDGs, namun negaranegara di dunia sepakat untuk bersama-sama mencapai 17 tujuan dari SDGs, yang diilustrasikan dengan gambar berikut:

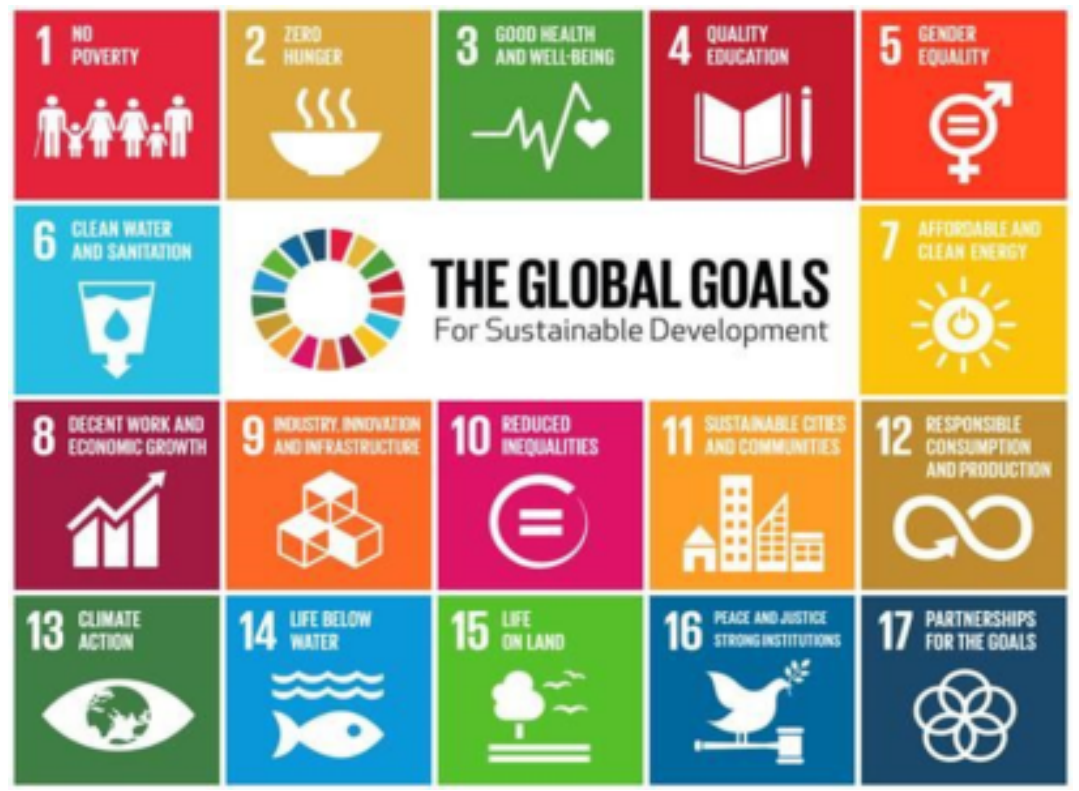

Gambar 1. 17 Tujuan SDGs (United Nations, n.d)

Siswa tingkat SMA/MA sederajat pada hari ini yang berusia antara 16-18 tahun adalah tunas bagi pencapaian SDGs pada tahun 2030, yang saat itu mereka akan berusia 29-31 tahun. Mereka adalah aktor dan bagian dari kepemimpinan baru di negara Indonesia, termasuk di kota Pekanbaru. Oleh sebab itu, persoalan-persoalan yang disasar dalam 17 tujuan SDGs haruslah mereka pahami. Lebih daripada itu, mereka juga harus terlibat aktif dalam mencapai tujuan-tujuan $S D G s$ yang dimaksud, dimulai saat ini juga.

Salah satu persoalan serius di tengah-tengah kota Pekanbaru adalah rendahnya partisipasi masyarakat (termasuk siswa tingkat SMA/MA sederajat) terkait masalah sampah. Kelemahan pemerintah kota Pekanbaru dalam mengelola sampah disebabkan oleh persoalan internal di dinas terkait dan tidak optimalnya kerja pihak ketiga sebagai mitra strategis (pihak swasta) yang dikontrak. Kondisi ini diperparah oleh rendahnya tingkat partisipasi dan kesadaran masyarakat dalam menyelesaikan permasalahan sampah. Sebagaian masyarakat kota ini membuang sampah sembarangan dan tidak menjalankan sistem 3R (reuse, reduce, recycle). Meskipun ada sebagian masyarakat yang kecewa dengan rendahnya kesadaran masyarakat terkait masalah sampah dan marah melihat kondisi sampah di kota Pekanbaru, tetap saja kesadaran masyarakat masih rendah. Bukti kekecewaan dan kemarahan sebagian masyarakat ini dapat dilihat di kelurahan Delima, Kecamatan tampan, di mana masyarakat memasang papan pemberitahuan yang bertuliskan "Ya Allah KUTUKLAH orang yang membuang sampah di area ini" seperti gambar di bawah ini: 


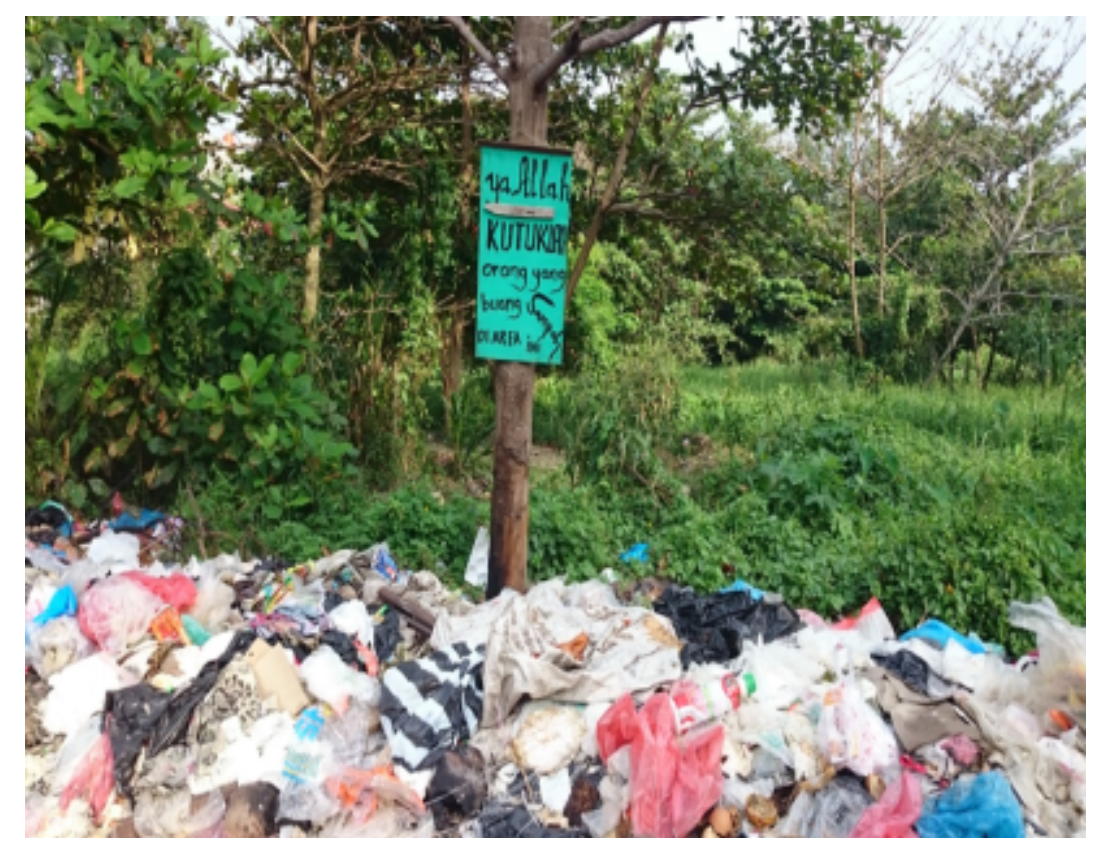

Gambar 2. Contoh Respon Negatif Masyarakat

Persoalan sampah menjadi ancaman serius saat ini dan di masa yang akan datang di kota Pekanbaru. Oleh sebab itu, generasi mudanya, siswa tingkat SMA/MA sederajat adalah tunas yang akan tumbuh menjadi duta $S D G s$ dan juga sebagai subjek utama yang harus menyadari akan pentingnya hal ini. Permasalahan sampah sudah mencuat sejak tahun 2015 dan hingga 2017 masih menjadi pekerjaan rumah yang serius. Tak dapat dipungkiri bahwa kota Pekanbaru mengalami tingkat pertumbuhan jumlah penduduk yang cukup tinggi, yang bermakna bahwa sampah juga akan bertambah, sehingga partisipasi masayarakat terkait persoalan sampah sangat diperlukan. Tidak ada partisipasi masyarakat tanpa adanya pemberdayaan masyarakat. Dalam konteks ini, kegiatan pengabdian masyarakat di kota Pekanbaru dengan menyasar tunas-tunas muda menjadi suatu pilihan yang tepat untuk dilaksanakan. Dengan latar belakang ini, penting bagi kita untuk memahami bahwa keberhasilan pembangunan secara umum dan tujuan SDGs hanya dapat tercapai secara optimal apabila terjalin sinergi dan kerjasama yang baik antara pemerintah, masyarakat dan pihak swasta.

Sesuai dengan latar belakang di atas, maka idenfikasi masalah dalam pengabdian ini adalah sebagai berikut: (1) rendahnya pengetahuan dan kesadaran masyarakat (termasuk siswa tingkat SMA/MA sederajat) tentang $S D G s$, terutama tujuan no 11 dan 12; dan (2) rendahnya pemberdayaan dan tingkat partisipisasi siswa SMA/MA sederajat terhadap capaian tujuan SDGs. Adapun tujuan umum dari kegiatan pengabdian ini adalah untuk menambah pengetahuan dan kesadaran siswa tingkat SMA/MA sederajat di kota Pekanbaru, sehingga muncul animo, partisisipasi dan kegiatan pemberdayaan dalam rangka percepatan pencapaian target $S D G s$, terutama tujuan no. 11 dan 12. Sedangkan tujuan khusus dari kegiatan pengabdian ini adalah sebagai berikut: (1) memberikan penguatan terhadap pengetahuan, kesadaran dan pertisipasi terkait $S D G s$, khususnya tujuan 11 dan 12 bagi siswa tingkat SMA/MA sederajat di kota Pekanbaru; (2) terciptanya pemberdayaan siswa tingkat SMA/MA sederajat di kota Pekanbaru terkait SDGs, terutama tujuan no.11 dan 12, khususnya masalah sampah; (3). Siswa peserta pelatihan dan pemberdayaan SDGs menjadi 'tunas' bagi lahirnya gerakan-gerakan dan/atau forum- 
forum peduli SDGs yang bersandar pada slogan 'global challenges, local solutions' (tantangan global, solusi lokal).

Adapun manfaat yang diharapkan dari kegiatan pengabdian masyrakat ini adalah sebagai berikut: (1) secara teoritis; manfaat pengabdian masyarakat ini diharapkan dapat memberikan tambahan dan penguatan pengetahuan tentang SDGs kepada siswa peserta pelatihan, terutama tujuan no.11 dan 12 ; (2) secara praktis; pengabdian masyarakat ini bermanfaat dalam peningkatan partisipasi dan pemberdayaan siswa peserta khususnya dan masyarakat luas pada umumnya untuk menyelesaikan persoalan sampah di kota Pekanbaru.

\section{TINJAUAN PUSTAKA}

Kegiatan pengabdian terkait SDGs, tujuan no. 11 dan 12 menggunakan konsepkonsep yang relevan dalam memahami dan menyikapi isu ini. Konsep-konsep yang akan dibahas di sini telah banyak dipelajari dan dikembangkan oleh para ahli bidang terkait yaitu partisipasi dan pemberdayaan.

\section{Konsep Partisipasi}

Menurut Isbandi (2007) partisipasi merupakan keikutsertaan seseorang dalam proses pengidentifikasian masalah dan potensi yang ada dalam masyarakat, pemilihan dan pengambilan keputusan tentang alternatif solusi untuk menagani masalah, pelaksanaan upaya mengatasi masalah, dan keterlibatan seseorang dalam proses mengevaluasi perubahan yang terjadi. Budiono (2005) mendefinikan partisipasi sebagai peran serta, atau keikutsertaan seseorang dalam suatu kegiatan bersama-sama dengan orang lain untuk mencapai tujuan tertentu. Sedangkan Soekanto (1993) mendefinisikasn partisipasi sebagai proses identifikasi atau menjadi peserta, suatu proses komunikasi atau kegiatan bersama dalam suatu situasi sosial tertentu. Nikmatullah (1991) menyatakan bahwa ada beberapa jenis partisipasi, salah satunya adalah partisipasi sosial berupa keterlibatan dalam kegiatan sosial demi kepentingan bersama.

Mikkelsen (1999) mengkategorikan partisipasi ke dalam 6 jenis pengertian, diantaranya: (1) partisipasi adalah kontribusi sukarela dari masyarakat kepada proyek tanpa ambil serta dalam keputusan; (2) partisipasi adalah pemekaan pihak masyarakat untuk meningkatkan kemauan menerima dan kemauan untuk menanggapi proyek-proyek pembangunan; (3) partisipasi adalah keterlibatan sukarela oleh masyarakat dalam perubahan yang ditentukannya sendiri; (4) partisipasi adalah suatu proses yang aktif, yang mengandung arti bahwa orang atau kelompok yang terkait, mengambil inisiatif dan mengunakan kebebasan untuk melakukan hal itu; (5) partisipasi adalah pemantapan dialog masyarakat setempat dengan para staf yang melakukan persiapan, pelaksanaan, monitoring proyek, agar memperoleh informasi mengenai konteks lokal, dan dampakdampak sosial; dan (6) partisipasi adalah keterlibatan masyarakat dalam pembangunan diri, kehidupan dan lingkungan mereka.

Adapun tujuan partisipasi menurut Schiller dan Antlov (dalam Sumarto, 2009) sebagai berikut: (1) menciptakan visi bersama; partisipasi memberi ruang yang luas bagi lahirnya visi hasil pemikiran bersama; (2) membangun rencana; visi dan misi dapat dijalankan dengan optimal apabila terdapat pelibatan dan/atau partisipasi dari berbagai komponen masyarakat; (3) mengumpulkan gagasan; partisipasi juga dapat memberi ruang bagi terkumpulnya berbagai gagasan yang berbeda, memperkaya pemikirian dan memperbanyak solusi bagi penyelesaian berbagai persoalan masyarakat; (4) menentukan prioritas dan membuat pilihan; aktivitas partisipasi dapat memperkaya wacana penentuan prioritas kegiatan bersama; (5) menjaring aspirasi; adanya partisipasi dapat menjadi 
wadah bagi penerimaan terhadap berbagai masukan dan aspirasi dari masyarakat dalam memecahkan berbagai persoalan; (6) mengumpulkan informasi; partisipasi juga memberikan kesempatan lebih baik untuk mengumpulkan informasi dan menganisa situasi.

\section{Konsep Pemberdayaan}

Pemberdayaan merupakan suatu proses dan upaya memperoleh atau memberikan daya, kekuatan atau kemampuan kepada individu dan masyarakat yang belum atau kurang berdaya supaya dapat mengidentifikasi, menganalisa, menetapkan kebutuhan dan potensi serta masalah yang dihadapi dan sekaligus memilih alternatif pemecahannya dengan mengoptimalkan sumber daya dan potensi yang dimiliki secara mandiri (Widjajanti, 2011). Peran pemberdayaan masyarakat sebagai suatu proses di tengah-tengah masyarakat, terutama bagi yang kurang memiliki akses ke sumber daya pembangunan akan sangat berpengaruh untuk meningkatkan partisipasi masyarakat dalam pembangunan dan pada akhirnya terwujudlah kemandirian mereka. Pemberdayaan masyarakat disebut juga sebagai proses siklus terus menerus, proses partisipatif, sehingga anggota masyarakat dapat bekerja sama dalam tim baik dalam bentuk formal ataupun informal, saling berbagi pengetahuan dan pengalaman serta berusaha mencapai tujuan bersama (Aziz, Suhartini \& Halim, 2005).

Adapun tujuan pemberdayaan masyarakat adalah sebagai berikut (Wibhawa, Raharjo \& Budiarti, 2010): (1) bangkitnya partispasi warga masyarakat. Ini dimaksudkan bahwa pemberdayaan masyarakat memerlukan partisipasi. Namun, pada saat yang sama, adanya partisipasi masyarakat menandakan bahwa masyarakat di suatu lingkungan sudah menunjukkan keterlibatan dalam menyelesaikan suatu persoalan di tengah kehidupan bersama mereka, terlepas apakah mereka benar-benar sudah berdaya, mandiri ataupun baru sebatas ikut-ikutan. Meski demikian, ini adalah langkah awal yang baik bagi terciptanya masyarakat yang berdaya; (2) memiliki kemampuan atau berdaya. Pemberdayaan juga berorientasi agar masyarakat atau suatu komunitas memiliki kemampuan untuk menyelesaikan persoalan bersama yang mereka hadapi. Pada saat yang sama, mereka juga secara sadar dan penuh inisiatif merencanakan, menjalankan, memonitoring dan mengevaluasi program-program yang mereka buat bersama; dan (3) terciptanya integrasi masyarakat untuk berdikari dalam membangun diri mereka sendiri.

Pemberdayaan juga bertujuan agar tercipta masyarakat atau komunitas yang terintegrasi, saling berinteraksi, terhubungkan dan mereka secara mandiri ataupun bersama-sama menyelesaikan masalah di tengah-tengah kehidupan mereka. Kemampuan mereka berdikari ini lah yang menjadi bukti bahwa mereka adalah komunitas yang berdaya. Sitepu (2010) mengulas bahwa adanya kemandirian dalam suatu kelompok masyarakat untuk menyelesaikan permasalahan mereka dengan mengedapankan kreatitivitas dengan sendirinya dapat berujung pada peningkatan kualitas hidup. Ilmu pengetahuan, ketarampilan dan sikap memiliki peranan penting dalam membangun kemandirian. Mubarak (2010) menekankan bahwa proses pemberdayaan masyarakat semestinya juga didampingi oleh suatu tim fasilitator yang bersifat multidisiplin. Ini bermakna bahwa persoalan-persoalan yang dihadapi masyarakat sering sekali harus diselesaikan dengan menggunakan metode yang multidisiplin. Pendekatan yang berpedoman pada satu disiplin atau bidang ilmu saja, sering sekali tidak cukup untuk menganalisa dan memberikan jalan keluar yang terbaik.

\section{METODE PELAKSANAAN}


Seluruh tahap kegiatan pengabdian ini dilaksanakan dalam waktu 3 bulan, meliputi tahapan persiapan, pelaksanaan dan pelaporan. Dalam pelaksanaannya, kegiatan pengabdian ini dilakukan dalam bentuk pelatihan dan pemberdayaan. Tim pengabdi mengumpulkan seluruh peserta yang merupakan perwakilan dari beberapa sekolah tingkat SMA/MA sederajat di kota Pekanbaru. Kegiatan pelatihan dan pemberdayaan ini dilakukan di dalam dan di luar ruangan yang disertai dengan focus group discussion $(F G D)$ dan kegiatan praktek, seperti praktek manajemen sampah.

\section{HASIL DAN PEMBAHASAN}

Kegiatan pengabdian ini memiliki beberapa hasil, utamanya adalah pemahaman generasi tunas tentang masalah sampah di kota Pekanbaru dan tujuan $S D G s$ dan kesadaran peran dan kontribusi mereka dalam mewujudkan lingkungan bebas sampah.

\section{Pemahaman tentang Masalah Sampah di Kota Pekanbaru dan Tujuan SDGs}

Sampah merupakan salah satu masalah yang ada di kota Pekanbaru dan sering menjadi keluhan masyarakat. Pemerintah kota Pekanbaru telah dan sedang berupaya mengatasi masalah sampah, namun hasilnya belum sesuai dengan harapan masayarakat. Dalam kegiatan ini, pelatihan diarahkan pada pembahasan berbagai masalah sampah di kota Pekanbaru dikaitkan dengan isu-isu global, kesehatan, keamanan dan sosiologi di mana genarasi tunas menjadi sasaran utamanya. Berkaitan dengan globalisasi, sampah telah menjadi masalah bersama pemerintahan negara-negara di dunia dan PBB. Pemerintah kota Pekanbaru diharapkan memberikan perhatian yang serius dalam penyelesaian masalah sampah di wilayahnya agar dapat mendukung tujuan SDGs yaitu sustainable cities and communities dan responsible consumption and production.

Dalam hal kesehatan, sampah menjadi sumber penyebab berbagai penyakit di tengah-tengah masyarakat kota. Banyaknya masyarakat yang belum menyadari bahaya sampah dan penularan penyakit menyebabkan masyarakat masih menerapkan budaya membuang sampah di tempat-tempat publik ataupun di pinggir-pinggir jalan. Selain merusak pandangan, kondisi seperti ini menyebabkan mudahnya masyarakat rentan terhadap berbagai penyakit. Isu sampah juga merupakan salah satu isu keamanan di mana sampah menjadi ancaman bagi manusia. Kebersihan lingkungan dan kesehatan masyarakat merupakan sasaran dari masalah sampah ini, sementara setiap individu masyarakat memiliki hak atas keindahan dan kebersihan lingkungan dan kebebasan atas berbagai penyakit khususnya yang disebabkan oleh sampah.

\section{Kesadaran terhadap Peran dan Kontribusi Generasi Tunas}

Para generasi tunas sebagai bagian dari komunitas masyarakat memiliki peran penting dalam mencegah dan mengatasi masalah sampah di kota Pekanbaru. Generasi tunas merupakan generasi terdidik yang memiliki kesadaran atau mudah diarahkan agar memiliki kesadaran dalam mewujudkan lingkungan dan masyarakat yang sehat. Mereka dapat berperan di lingkungan masing-masing seperti lingkungan sekolah dan rumah. Dalam kegiatan ini, generasi tunas (peserta) didorong dan dibina dalam mewujudkan lingkungan bebas sampah di lingkungan sekolah mereka melalui berbagai kegiatan dan program seperti gerakan bebas sampah, mempersiapkan tempat pembuangan sampah (tong sampah) serta pemanfaatan sampah yang dapat didaur ulang menjadi benda-benda yang bernilai ekonomis atau estetis. Kegiatan ini tentunya didukung oleh pengelola sekolah seperti kepala sekolah, guru dan lainnya. Kegiatan ini utamaya telah berupaya mewujudkan kesadaran dan mengarahkan kesadaran tersebut menjadi tindakan nyata di mana generasi tunas memiliki peran penting dalam mewujudkan kota dan masyarakat 
yang berkelanjutan serta konsumsi dan produksi yang bertanggungjawab sejalan dengan moto kota Pekanbaru yaitu Masyarakat Madani.

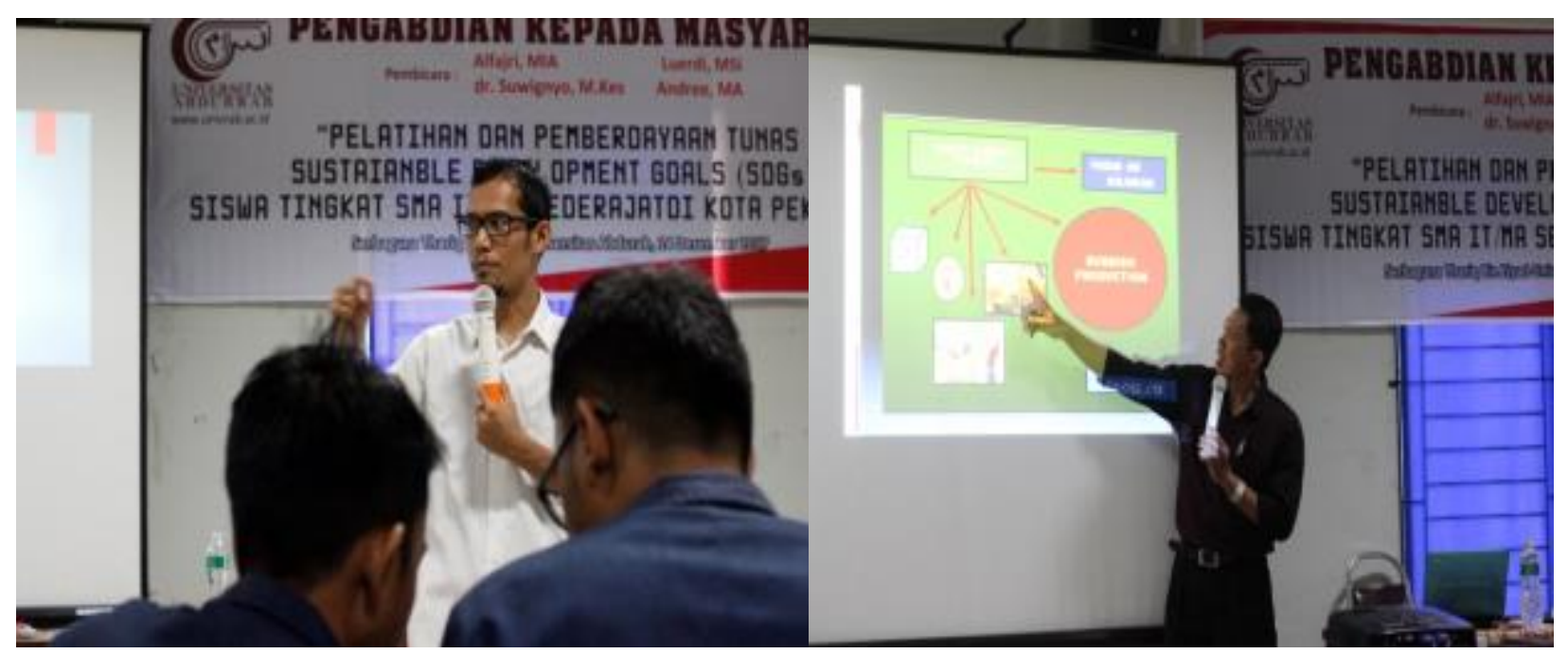

Gambar 3. Pemaparan oleh Tim Pengabdi

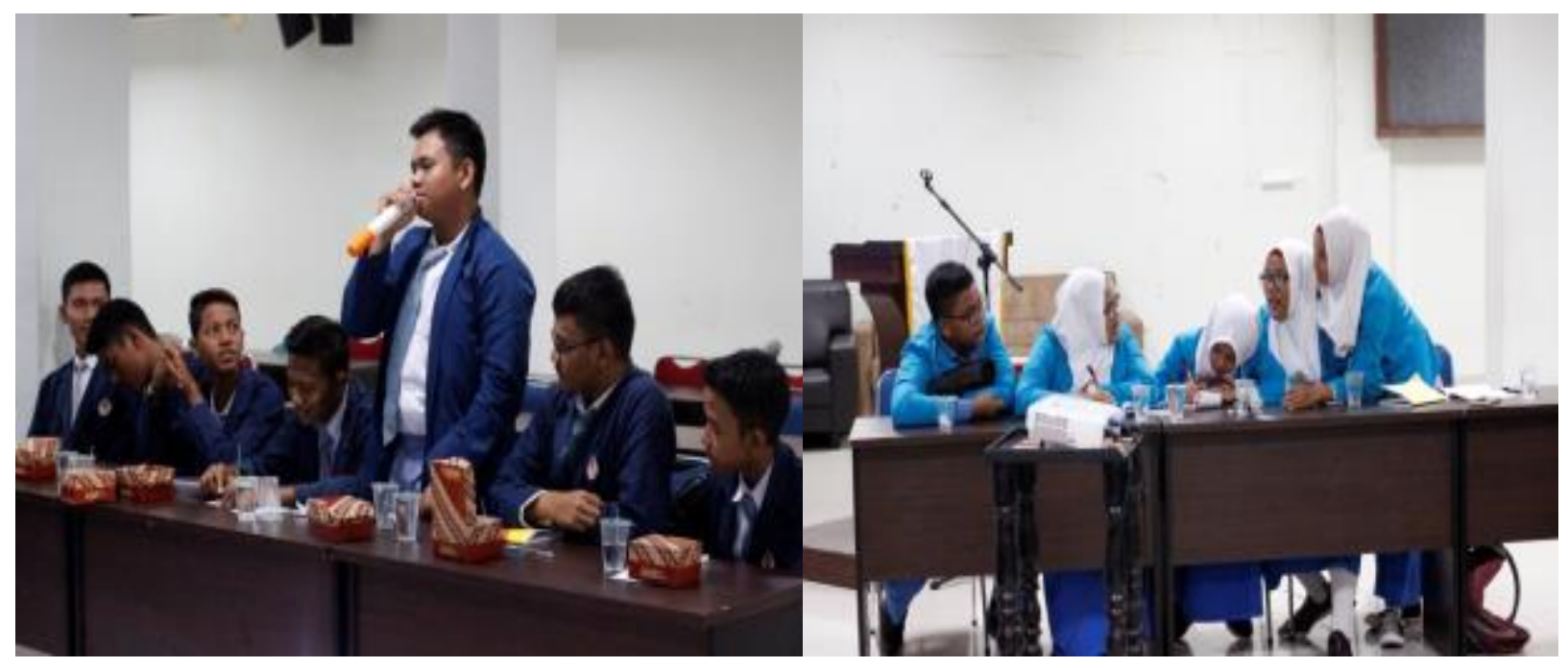

Gambar 4. Aktifitas Peserta

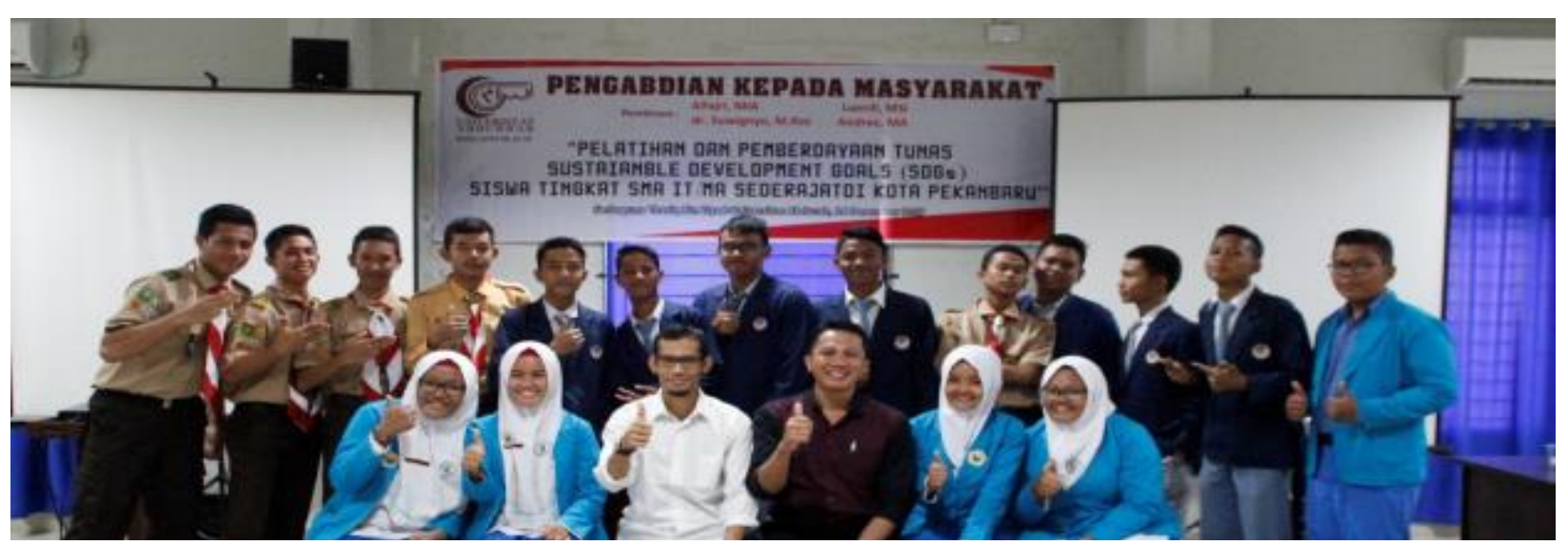

Gambar 5. Tim Pengabdi dan Peserta 


\section{KESIMPULAN}

Kegiatan pengabdian ini telah dilaksanakan dengan baik dan memberikan hasil yang positif bagi generasi tunas yaitu siswa SMA/MA sederajat di kota Pekanbaru dan lingkungan mereka. Generasi tunas sebagai peserta dalam kegiatan pengabdian ini mampu menjadi pelopor dan penggerak dalam mewujudkan lingkungan bebas sampah khususnya di lingkungan sekolah ataupun rumah. Kedepannya, peran mereka bisa ditingkatkan tidak hanya di lingkungan sekolah tapi juga lingkungan yang lebih luas dan membimbing masyarakat agar membudayakan hidup sehat dan menjadi masyarakat yang bertanggungjawab terhadap sampah yang mereka hasilkan dan berperan dalam mewujudkan kota dan masyarakat yang berkelanjutan.

\section{DAFTAR PUSTAKA}

[1]. Aziz, M. A., Suhartini, R., \& Halim, A. (2005). Dakwah Pemberdayaan Masyarakat Paradigma Aksi dan Metodologi. Yogyakarta: PT. LKIS Pelangi Aksara.

[2]. Budiono. (2005). Kamus Ilmiah Populer Internasional. Surabaya: Alumni.

[3]. Isbandi, R.A. (2007). Perencanaan Paritisipatoris Berbasis Aset Komunitas: dari Pemikiran menuju Penerapan. Depok: UI Press.

[4]. Mikkelsen, B. (1999). Metode Penelitian Partisipatoris dan Upaya-Upaya Pemberdayaan: Sebuah Buku Pegangan bagi Para Praktisi Lapangan. Jakarta: Yayasan Obor.

[5]. Mubarak, Z. (2010). Evaluasi Pemberdayaan Masyarakat Ditinjau dari Proses Pengembangan Kapasitas pada Kegiatan PNPM Mandiri Perkotaan di Desa Sastrodirjan Kabupaten Pekalongan. Tesis. Universitas Diponegoro, Semarang.

[6]. Nikmatullah, D. (1991). Partisipasi Pemimpin Desa dalam Pembinaan Kelompok Tani di Rawa Srigi, Lampungan Selatan. Yogyakarta: Badan Penelitian Universitas Gadjah Mada.

[7]. Sitepu, P.A. (2010). Negara dan Masyarakat Sipil dalam Perspektif Sejarah Politik Indonesia. Jurnal Politeia, 2(1), p.57-65.

[8]. Soekanto, S. (1993). Pembangunan Masyarakat Berwawasan Partisipasi. Jakarta: Yayasan Obor Indonesia.

[9]. Suharto, E. (2005). Membangun Masyarakat Memberdayakan Rakyat: Kajian Strategis Pembangunan Kesejahteraan Sosial dan Pekerjaan Sosial. Bandung, PT. Refika Aditama.

[10]. Sumarto, H.S.J. (2009). Inovasi, Partisipasi dan Good Governance. Jakarta: Yayasan Obor Indonesia.

[11]. United Nations. (n.d). Sustainable Development Goals (SDGs) and Disability. Diperoleh dari: https://www.un.org/development/desa/disabilities/aboutus/sustainable-development-goals-sdgs-and-disability.html

[12]. Widjajanti, K. (2011). Model Pemberdayaan Masyarakat. Jurnal Ekonomi Pembangunan. 12(1). p.15-27.

[13]. Wibhawa, B., Raharjo, S.T., \& Budiarti, M. (2010). Dasar-Dasar Pekerja Sosial. Bandung: Widya Padjadjaran. 